\title{
HUBUNGAN ANTARA FAKTOR SOSIAL EKONOMI DENGAN PERSEPSI PETERNAK TERHADAP PENGEMBANGAN USAHA PETERNAKAN SAPI PERAH DI KOTA TOMOHON
}

\author{
Suryana D.S. Muhammad* R. A. J. Legrans**, E. Wantasen**, J. \\ Lainawa**
}

Fakultas Peternakan, Universitas Sam Ratulangi Manado, 95115

\begin{abstract}
ABTRAK
Pengembangan usaha peternakan sapi perah erat kaitannya dengan peternak, dan setiap peternak memiliki latar belakang sosial ekonomi yang berbeda. Faktor sosial ekonomi peternak nantinya akan mempengaruhi persepsinya terhadap usaha yang dijalankan. Permasalahannya apakah faktor sosial ekonomi mempengaruhi persepsi peternak, bagaimana persepsi peternak terhadap usaha tersebut dan seberapa jauh hubungan antara faktor sosial ekonomi dengan persepsi peternak. Tujuan penelitian adalah untuk mengetahui faktor-faktor sosial ekonomi peternak sapi perah; persepsi peternak terhadap pengembangan usaha peternakan sapi perah; dan menganalisis hubungan faktor-faktor sosial ekonomi peternak dengan persepsi terhadap pengembangan usaha peternakan sapi perah di kota Tomohon. Penelitian ini dilaksanakan di 4 Kecamatan di kota Tomohon dengan jumlah responden 30 peternak. Data dalam penelitian adalah data primer dan data sekunder. Metode penentuan sampel dilakukan secara "Purposive Sampling" yaitu di 3 kecamatan. Hasil penelitian menunjukkan peternak berumur 43-54 tahun sebanyak $40 \%$, lama pendidikan sebagian besar peternak (46,7\%) 12-16 tahun. Peternak menekuni usaha beternak sapi perah selama 2-3 tahun. Frekuensi peternak dalam mengikuti penyuluhan serta pelatihan sebagian besar 1-2 kali $(76,6 \%)$ dan $90 \%$
\end{abstract}

*Alumni Fakultas Peternakan Unsrat **Jurusan Sosial Ekonomi Peternakan peternak berpendapatan Rp. $1.350 .000-$ Rp. 3.499.800. Persepsi peternak terhadap pengembangan usaha peternakan sapi perah di kota Tomohon adalah baik. Lama usaha berhubungan sangat nyata dengan persepsi peternak terhadap pengembangan usaha peternakan sapi perah di Kota Tomohon.

Kata Kunci: Faktor social ekonomi, persepsi peternak, usaha sapi perah, Kota Tomohon.

\section{ABSTRACT}

RELATIONSHIP BEWEEN ECONOMICAL SOCIAL FACTOR AND HOUSEHOLD PERSEPTION ON DAIRY FARM DEVELOPMENT IN TOMOHON MUNICIPALITY. Dairy farm development was importantly connected with household farmer. Each household farmer had different economical social background. The objective of this study was to evaluate the relationship between economical social factor and household perception on dairy farm development in Tomohon municipality.This study was conducted at four districts in Tomohon municipality using thirty respondents of household farmers. Samples were determined by purposive sampling method involving three districts. Primer secunder data were used in this study. Results showed that household farmers at ages of 43 to 54 years old were 40 percents. The education period of the animal household was ranging from 12 to 16 years $(46.7 \%)$. The experiemces as animal household of dairy cattle were ranging from 2 to 3 years. The frequency attending extension and skill training were ranging from 1 to 2 times 
(76.6\%), and 90 percents of animal household had income from $\mathrm{Rp}$. $1,350,000$ to Rp. $3,499,800$ per month. Perseptions of animal household on dairy farm development in Tomohon municipality were generally good. Period of animal farm highly correlated with the perception household farmer in development of dairy farm in Tomohon municipality.

Kata Kunci: Economical social factor, household farmer perception, dairy farm, Tomohon municipality.

\section{PENDAHULUAN}

Energi merupakan salah satu hasil metabolisme karbohidrat, protein dan lemak. Energi berfungsi sebagai zat tenaga untuk metabolisme, pertumbuhan, pengaturan suhu dan kegiatan fisik (IOM, 2002). Susu merupakan pangan sumber energi yang kaya akan protein (Phillips, 2009 dan Bos, 2000). Sapi perah adalah salah satu ternak penghasil susu yang sangat dominan dibandingkan ternak perah lainnya. Produksi susu terbanyak di Indonesia sampai tahun 2012 di hasilkan oleh provinsi Jawa timur yaitu 554.312 ton (Kementerian Pertanian RI, 2013). Sejak tahun 2010 populasi ternak sapi perah di Sulawesi Utara terus meningkat dari 17 ekor dan menjadi 216 ekor di tahun 2012 (Dirjen Peternakan RI, 2013). Menurut data yang diperoleh dari Dinas Pertanian dan Peternakan Sulawesi Utara (2013) bahwa di tahun 2011 sampai tahun 2013 produksi susu dari sapi perah belum memberikan kontribusi.

\section{Pendekatan perencanaan}

wilayah secara komprehensif dan berkelanjutan merupakan usaha pemerintah untuk meningkatkan produksi pertanian secara merata (Departemen Pertanian RI, 2013). Sulawesi utara merupakan salah satu kawasan yang telah ditetapkan sebagai kawasan pengembangan ternak sapi oleh Kementerian Pertanian RI (Departemen Pertanian RI, 2013). Kelompok penerima bantuan sapi perah terbanyak di Sulawesi Utara yaitu di Kota Tomohon sejak tahun 2011 (Dinas Pertanian dan Peternakan Sulawesi Utara, 2013).

Persepsi adalah pandangan atau sikap terhadap sesuatu hal yang menumbuhkan motivasi, dorongan, kekuatan dan tekanan yang menyebabkan seseorang melakukan atau tidak melakukan sesuatu (Sarwani, 2003). Dua faktor yang mempengaruhi proses pembentukan persepsi yaitu faktor struktural yang ditentukan oleh jenis dan bentuk 
rangsangan yang diterima. Sedangkan, faktor fungsional ialah karakteristik orang yang memberi respons terhadap rangsangan tersebut (Rakhmat, 2004). Karakteristik sosial ekonomi berpengaruh terhadap persepsi seseorang, anggota sistem sosial yang lebih inovatif mempunyai karakteristik sosial ekonomi sebagai berikut: tingkat pendidikan lebih tinggi, mempunyai unit skala usaha tani yang lebih luas serta orientasi usahanya bersifat komersil (Tarigan, 1987).

\section{Pengembangan usaha}

peternakan sapi perah erat kaitannya dengan peternak. Persepsi perlu diidentifikasi untuk mengetahui pendapat peternak tentang kesesuaian pengembangan usaha beternak sapi perah, manfaat yang diperoleh peternak dari usaha beternak sapi perah dan harapan peternak dengan menjalankan usaha beternak sapi perah di kota Tomohon. Persepsi peternak menjadi masalah penting untuk diteliti, sehingga kajian mengenai persepsi peternak pengelola sapi perah perlu dilakukan. Hasil-hasil penelitian terdahulu menjadi tolok ukur dalam penelitian ini untuk selanjutnya mengetahui apakah faktor-faktor sosial ekonomi memiliki hubungan dengan persepsi peternak khususnya peternak sapi perah yang ada di kota Tomohon. Permasalahannya adalah : apakah faktor-faktor sosial ekonomi yang berhubungan dengan persepsi peternak mengenai pengembangan usaha beternak sapi perah, bagaimana persepsi peternak terhadap program pemerintah dalam pengembangan usaha peternakan sapi perah, dan seberapa jauh hubungan faktor-faktor sosial ekonomi dengan persepsi peternak terhadap pengembangan usaha peternakan sapi perah di kota Tomohon. Penelitian ini bertujuan untuk mengetahui faktor-faktor sosial ekonomi peternak sapi perah, persepsi peternak terhadap pengembangan usaha peternakan sapi perah, dan menganalisis hubungan faktor-faktor sosial ekonomi peternak dengan persepsi terhadap pengembangan usaha peternakan sapi perah di kota Tomohon.

\section{METODE DAN MATERI PENELITIAN}

Penelitian ini telah dilaksanakan di Kota Tomohon 
Provinsi Sulawesi Utara. Penentuan kecamatan sampel dilakukan secara "Purposive Sampling", yaitu 3 kecamatan dengan populasi terbanyak yang didasarkan pada tujuan penelitian (Singarimbun dan Efendi, 1989). Sampel yang diambil dari 3 kecamatan yaitu Kecamatan Tomohon Utara (Desa Kakaskasen
II), Kecamatan Tomohon Timur (Desa Paslaten II), dan Kecamatan Tomohon Tengah (Desa Kamasi dan Matani II) (Tabel 1). Penentuan responden dilakukan secara cacah lengkap terhadap peternak yang mengelola bantuan sapi perah yaitu sebanyak 30 responden secara keseluruhan.

Tabel 1. Kelompok peternak penerima bantuan sapi perah di Kota Tomohon tahun (2011-2012)

\begin{tabular}{|c|c|c|c|c|c|c|}
\hline $\begin{array}{c}\text { No } \\
\text {. }\end{array}$ & $\begin{array}{c}\text { Nama } \\
\text { Kelompok }\end{array}$ & Ketua & Desa & Kecamatan & $\begin{array}{c}\text { Populasi } \\
\text { Awal }\end{array}$ & $\begin{array}{l}\text { Tujuan } \\
\text { Usaha }\end{array}$ \\
\hline 1. & Anugerah & Adri Mongi & Paslaten II & $\begin{array}{l}\text { Tomohon } \\
\text { Timur }\end{array}$ & 25 & Pembibitan \\
\hline 2. & $\begin{array}{l}\text { Zano } \\
\mathrm{Ne} \text { Wuku }\end{array}$ & Max Rambing & Matani II & $\begin{array}{l}\text { Tomohon } \\
\text { Tengah }\end{array}$ & 25 & Pembibitan \\
\hline 3. & Maju Bersama & Albert Gontha & Kamasi & $\begin{array}{l}\text { Tomohon } \\
\text { Tengah }\end{array}$ & 25 & Pembibitan \\
\hline 4. & $\begin{array}{l}\text { Ramulu } \\
\text { Sangkor }\end{array}$ & Rudi Lumi & Kakaskasen II & $\begin{array}{l}\text { Tomohon } \\
\text { Utara }\end{array}$ & 23 & Budidaya \\
\hline
\end{tabular}

Sumber: Dinas Pertanian dan Peternakan Provinsi Sulawesi Utara (2013)

Sumber data yang digunakan adalah data primer merupakan data yang diperoleh secara langsung dari responden melalui wawancara dengan menggunakan daftar pertanyaan (kuisioner) dan data sekunder ialah data yang diperoleh dari instansi pemerintah atau lembaga terkait, antara lain; Dinas Pertanian, Peternakan dan Perkebunan Kota Tomohon, Dinas

Pertanian dan Peternakan Provinsi Sulawesi Utara, Badan Pusat Statistik Sulawesi Utara, Badan Ketahanan Pangan Sulawesi Utara, Departemen Pertanian RI.

$\begin{array}{lrr}\text { Variabel } \quad \text { dan } & \text { batasan } \\ \text { pengukuran } & \text { serta } & \text { definisi } \\ \text { operasional, yaitu : (1) } & \text { Persepsi ialah } \\ \text { proses } & \text { pemahaman } & \text { ataupun } \\ \text { pemberian } & \text { makna atas } & \text { suatu } \\ \text { informasi } & \text { terhadap } & \text { stimulus. }\end{array}$


Stimulus didapat dari proses penginderaan terhadap obyek, peristiwa atau hubungan-hubungan antar gejala dan ditafsirkan melalui pandangan, penilaian serta tanggapan peternak, diantaranya:

Kesesuaian menyangkut tanggapan peternak mengenai lingkungan usaha dan pengetahuan peternak; (b) Manfaat menyangkut tanggapan peternak mengenai keuntungan apa yang diperoleh/dirasakan peternak dalam mengelola usaha ternak perah; (c) Harapan menyangkut tanggapan peternak mengenai pengembangan usaha, kemudahan dalam pemeliharaan ternak serta dukungan lembaga terkait dalam pengelolaan usaha tersebut, terhadap usaha pengembangan peternakan sapi perah dikota Tomohon. Ukuran yang digunakan adalah ukuran ordinal yaitu (S) Setuju, (R) Ragu-ragu, dan (TS) Tidak Setuju. Penentuan skor yang diberikan apabila responden memilih setuju (S) pada suatu pernyataan yang dianggap cocok maka skor yang diperoleh adalah (3), apabila responden ragu-ragu (R) pada suatu pernyataan maka skor yang diperoleh (2) dan apabila responden tidak setuju (TS) dengan pernyataan maka skor yang diperoleh (1). (2) Peternak sapi perah ialah individu yang melakukan kegiatan beternak sapi perah atau memelihara ternak sapi perah penerima bantuan untuk dikelola usahanya dalam memenuhi kebutuhan hidupnya; (3) Umur ialah usia peternak saat dilakukan penelitian diukur dalam satuan tahun; (4) Pendidikan formal ialah pendidikan peternak yang terstruktur dan berjenjang (SD, SMP, SMA, PT) yang berstatus negeri maupun swasta, diukur dalam satuan tamat atau tidak tamat; (5) Pendidikan nonformal dalam hal ini ialah frekuensi peternak dalam mengikuti penyuluhan serta pelatihan; (6) Lama usaha ialah waktu yang digunakan dalam berusaha ternak sapi perah diukur dalam satuan tahun; (7) Pendapatan peternak yang diperoleh dari beternak sapi perah maupun yang diperoleh diluar beternak sapi perah per bulan, diukur dalam satuan rupiah.

Model analisis yang digunakan adalah (1) uji korelasi rank Spearman $\left(\mathrm{r}_{\mathrm{s}}\right)$ yang oleh Steel dan Torie (1991) model persamannya sebagai berikut: 


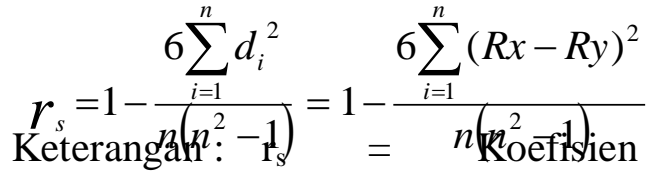
Korelasi Spearman

$\mathrm{d}_{\mathrm{i}}^{2}=$ beda pangkat dengan pasangan kecil

$\mathrm{n} \quad=$ jumlah sampel

(2) Uji Koefisien Kontingensi (KK) yang diturunkan dari uji chi square $\left(x^{2}\right)$ oleh Arikunto (2006). Model persamaannya sebagai yang diturunkan dari uji chi square $\left(x^{2}\right)$ oleh Arikunto (2006). Model persamaannya sebagai berikut:

Uji chi square $\left(x^{2}\right)$ :

$$
x^{2}=\sum \frac{\left(f_{0}-f_{e}\right)^{2}}{f_{e}}
$$

Uji Koefisien Kontingensi (KK)

$$
C=\sqrt{\frac{x^{2}}{x^{2}+n}}
$$

Keterangan: $x^{2}=$ uji chi square

fe = frekuensi yang diharapkan

$f_{o}=$ frekuensi yang

diperoleh/diamati

$n \quad=$ jumlah sampel

\section{HASIL DAN PEMBAHASAN}

Luas kota Tomohon adalah $147,21 \mathrm{Km}^{2}$, terdiri atas 5 kecamatan, kecamatan terluas adalah kecamatan Tomohon Utara $(42,28$ $\mathrm{Km}^{2}$ ) dan kecamatan Tomohon Tengah sebagai kecamatan dengan area yang terkecil $\left(9,41 \mathrm{Km}^{2}\right)$. Batasbatas pemerintahan wilayah Kota Tomohon Sebelah Utara, Timur, Barat dan Selatan berbatasan dengan Kabupaten Minahasa. Jumlah penduduk di Kota Tomohon pada akhir tahun 2012 tercatat 93,857 jiwa yang terdiri dari penduduk laki-laki sebanyak 47,265 jiwa dan jumlah penduduk perempuan sebanyak 45,592 jiwa.

Responden dalam penelitian ini berjumlah 30 orang adalah peternak yang merupakan anggota dari Kelompok Peternak Sapi Perah Anugerah, Zano ne Wuku, dan Ramulu Sangkor, yang berada di tiga Kecamatan di kota Tomohon. Data faktor sosial ekonomi peternak sapi perah dalam penelitian ini yaitu umur, pendidikan formal, lama usaha, pendidikan nonformal, dan pendapatan. Faktor sosial ekonomi peternak dapat dilihat pada Tabel 2. 
Tabel 2. Distribusi responden berdasarkan faktor sosial ekonomi peternak

\begin{tabular}{|c|c|c|c|}
\hline No. & Faktor sosial ekonomi Peternak & $\begin{array}{l}\text { Jumlah* } \\
\text { (Orang) }\end{array}$ & $\begin{array}{c}\text { Presentase } \\
(\%)\end{array}$ \\
\hline \multirow[t]{4}{*}{1} & Umur & & \\
\hline & $31-42$ tahun & 10 & 33,3 \\
\hline & $43-54$ tahun & 12 & 40 \\
\hline & $55-66$ tahun & 8 & 26,7 \\
\hline \multirow[t]{4}{*}{2} & Pendidikan formal & & \\
\hline & Tidak sekolah - tamat SD & 4 & 13,3 \\
\hline & Tidak tamat SMP - tamat SMP & 12 & 40 \\
\hline & Tidak tamat SMA - Perguruan tinggi & 14 & 46,7 \\
\hline \multirow[t]{4}{*}{3} & Lama usaha & & \\
\hline & 1 tahun & - & - \\
\hline & 2 tahun & 19 & 63,3 \\
\hline & 3 tahun & 11 & 36,7 \\
\hline \multirow[t]{4}{*}{4} & Pendidikan nonformal (penyuluhan/pelatihan) & & \\
\hline & $1-2$ kali & 23 & 76,6 \\
\hline & $3-4$ kali & 2 & 6,7 \\
\hline & $4-6$ kali & 5 & 16,7 \\
\hline \multirow[t]{4}{*}{5} & Pendapatan (diukur dari sebaran pendapatan responden) & & \\
\hline & Rp. $1.350 .000-$ Rp. 3.499 .800 & 27 & 90 \\
\hline & Rp. 3.500.000 - Rp. 6.750 .000 & 2 & 6,7 \\
\hline & Rp. $6.751 .000-$ Rp. 10.000 .000 & 1 & 3,3 \\
\hline
\end{tabular}

Keterangan: $* \mathrm{n}=30$

Persepsi adalah proses Persepsi peternak terhadap pemahaman ataupun pemberian pengembangan usaha peternakan makna atas suatu informasi terhadap stimulus. Stimulus didapat dari proses penginderaan terhadap obyek, peristiwa atau hubungan-hubungan antar gejala dan ditafsirkan melalui pandangan, penilaian serta tanggapan peternak. Persepsi peternak terhadap program pengembangan usaha peternakan sapi perah di Kota Tomohon dalam penelitian ini terdiri dari tiga butir, yaitu: 1) persepsi terhadap kesesuaian usaha; 2) persepsi terhadap manfaat usaha; dan 3) persepsi terhadap harapan usaha. sapi perah di Kota Tomohon dapat dilihat pada Tabel 3.

Tabel 3 menunjukkan bahwa jumlah skor secara keseluruhan adalah 2240, ini mengartikan bahwa persepsi peternak sapi perah terhadap pengembangan usaha peternakan sapi perah baik.

Hubungan antara faktor sosial ekonomi dengan persepsi peternak terhadap pengembangan usaha peternakan sapi perah di Kota Tomohon diukur dengan menggunakan korelasi rank 
Spearman $\left(\mathrm{r}_{\mathrm{s}}\right)$ dan uji Koefisien dari uji Chi-Square $\left(x^{2}\right)$. Hasil dari

Kontingensi (KK) yang diturunkan pengujian hubungan faktor

Tabel 3. Total skor persepsi peternak terhadap program pengembangan usaha peternakan sapi perah di Kota Tomohon

\begin{tabular}{ll}
\hline Aspek persepsi peternak & Total skor $^{*}$ \\
\hline Kesesuaian usaha & 765 \\
Manfaat usaha & 676 \\
Harapan peternak terhadap usaha & 799 \\
\hline Jumlah skor & 2240 \\
\hline
\end{tabular}

Keterangan: "Total skor= 900-1500= tidak baik; 1501-2100= kurang baik; $2101-2700=$ baik

Tabel 4. Koefisien Korelasi faktor sosial ekonomi dengan persepsi peternak terhadap pengembangan usaha peternakan sapi perah di Kota Tomohon

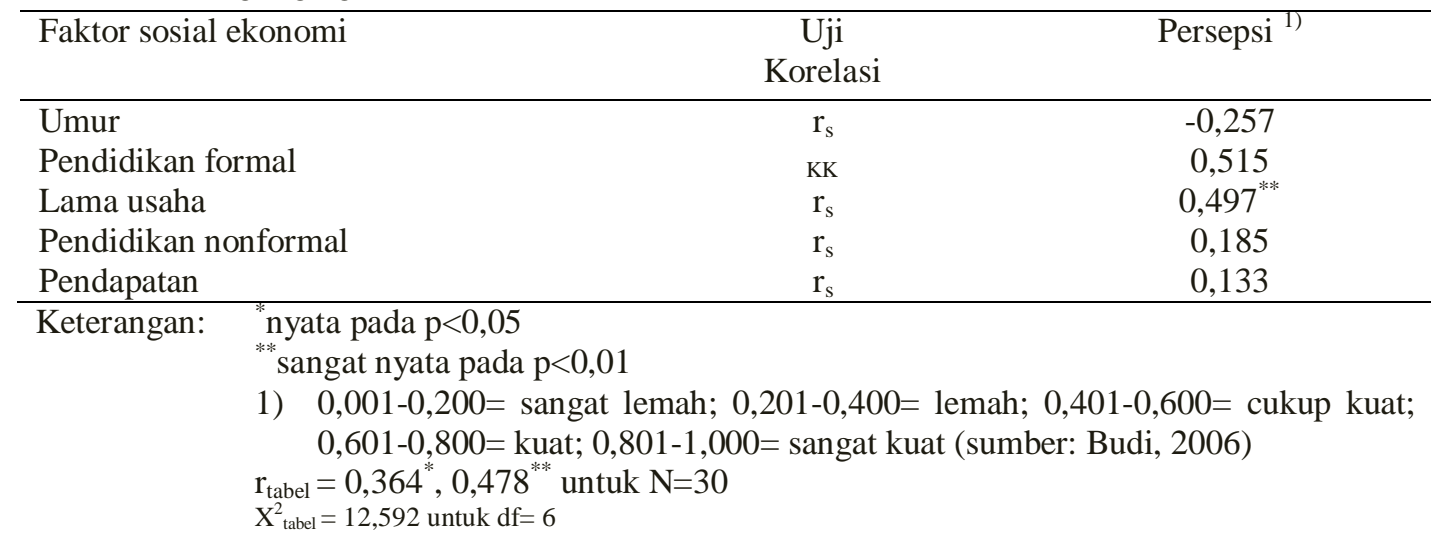

sosial ekonomi dengan persepsi terhadap pengembangan usaha peternakan sapi perah di Kota Tomohon disajikan pada Tabel 4.

\section{KESIMPULAN DAN SARAN}

Berdasarkan hasil penelitian dapat disimpulkan bahwa :

a. (40\%) peternak berumur $43-54$ tahun, sebagian besar peternak $(46,7 \%)$ menempuh pendidikan 12-16 tahun (SMA-Perguruan tinggi). Peternak menekuni usaha beternak sapi perah selama 2-3 tahun. Frekuensi peternak mengikuti penyuluhan dan pelatihan sebagian besar $(76,6 \%)$ 1-2 kali selama menekuni usaha peternakan sapi perah dan $(90 \%)$ peternak berpendapatan Rp.1.350.000 - Rp.3.499.800.

b. Persepsi peternak terhadap pengembangan usaha peternakan 
sapi perah di kota Tomohon adalah baik.

c. Lama usaha berhubungan sangat nyata dengan persepsi peternak mengenai pengembangan usaha peternakan sapi perah. Umur, pendidikan formal, pendidikan nonformal dan pendapatan tidak terdapat hubungan yang nyata dengan persepsi peternak mengenai pengembangan usaha peternakan sapi perah di Kota Tomohon.

Berdasarkan hasil penelitian maka disarankan hendaknya pemerintah secara rutin memberikan pelatihan serta penyuluhan kepada peternak, memprioritaskan kepentingan dan keinginan peternak dan memberikan sapi-sapi yang berkualitas untuk pengembangan usaha, serta perlunya mengikutsertakan peternak dalam penyusunan program.

\section{DAFTAR PUSTAKA}

Arikunto, S. 2006. Prosedur Penelitian: Suatu Pendekatan Praktik. Edisi Revisi VI. Jakarta: PT Rineka Cipta
Departemen Pertanian RI, 2013. Kawasan Komoditas Unggulan. Sekretariat Jenderal Kementerian Pertanian Biro perencanaan.

http://perencanaan.setjen.depta n.go.id. Diunduh 26 november 2013.

Dinas Pertanian dan Peternakan SULUT, 2013. Produksi Daging, Telur dan Susu Sulawesi utara. Kalasey.

Dinas Pertanian dan Peternakan SULUT, 2013. Data Kelompok Sapi Perah di Provinsi Sulawesi Utara. Kalasey.

Direktorat Jenderal Peternakan RI, 2013. Populasi Sapi Perah Menurut Provinsi. Jakarta.

Institute Of Medicin. 2002. Dietary Reference Intake for Energy, Carbohydrate, Fiber, Fat, Fatty Acids, Cholesterol, Protein, and Amino Acids. A Report of the Panel on Macronutrients, Subcommittees on Upper Reference Levels of Nutrients and Interpretation and Uses of Dietary Reference Intakes, and the Standing Committee on the Scientific Evaluation of 
Dietary Reference Intakes.

National Academies Press,

Washington, DC.

Kementerian Pertanian RI, 2013.

Produksi Susu Menurut

Provinsi. Jakarta. 2013.

http://deptan.go.id. Diunduh

12 November 2013.

Phillips SM et al, 2009. Peran susu dan protein berbasis kedelai dalam mendukung sintesis protein otot dan pertambahan protein otot pada orang muda dan tua . J Am Coll Nutr 2009; 28 (4) :343-354.

Rakhmat, J. 2004. Psikologi Komunikasi. Rosdakarya Group. Bandung.

Sarwani. 2003. Persepsi Karyawan terhadap Faktor-faktor Lingkungan Perusahaan yang Mempengaruhi Motivasi Kerja Karyawan Bagian Produksi. Skripsi. Fakultas Peternakan Institut Pertanian Bogor. Bogor.

Singarimbun M. dan S. Effendi 1989. Metode Penelitian Survey. LP3ES. Jakarta.

Steel, R. G. D. dan J. H. Torrie, 1991. Prinsip dan Prosedur Statistika. Suatu Pendekatan
Biometrik. Gramedia Pustaka Umum. Jakarta.

Tarigan, A. 1987. Persepsi Anggota Kelompok Peternak Terhadap Usaha Ternak Sapi Perah Di Kabupaten Sukabumi. Jawa Barat. Karya Ilmiah. Fakultas Peternakan Institut Pertanian Bogor. 
